\title{
RELEVANSI MATERI PEMBELAJARAN TEKNIK REFRIGERASI DI PERGURUAN TINGGI DAN DI SMK DENGAN STANDAR UJI KOMPETENSI
}

\author{
Deni Indrayani ${ }^{1}$, Inu H. Kusumah ${ }^{2}$, Enang S. Arifiyanto ${ }^{3}$ \\ Departemen Pendidikan Teknik Mesin \\ Universitas Pendidikan Indonesia \\ J1. Dr. Setiabudhi No. 207 Bandung 40154 \\ deni.indra17@gmail.com
}

\begin{abstract}
ABSTRAK
Penelitian ini bertujuan untuk menghasilkan deskripsi relevansi materi yang ada diperguruan tinggi dan di SMK dengan materi standar uji kompetensi khususnya materi kejuruan teknik refrigerasi. Metode yang digunakan dalam penelitian ini adalah deskriptif analitik dengan pendekatan kuantitatif. Teknik pengumpulan data berupa dokumentasi, wawancara, dan angket. Hasil penelitian menunjukan bahwa persentase relevansi materi teknik refrigerasi yang ada di perguruan tinggi sebesar 71,43\% dengan materi yang dibutuhkan untuk pembelajaran peserta didik dan $75 \%$ dengan materi yang digunakan untuk uji kompetensi di SMK. Persentase relevansi materi yang ada di SMK dengan materi yang digunakan untuk uji kompetensi sendiri sebesar 91,67\%. Persentase yang ada bukan berarti tidak sesuai secara keseluruhan melainkan ada sebagian materi yang merupakan materi pada pembelajaran lain. Dokumentasi relevansi materi teknik refrigerasi secara umum telah terpetakan dengan kebutuhan materi yang ada di SMK.
\end{abstract}

Kata kunci: relevansi, refrigerasi, standard, kompetensi.

\section{PENDAHULUAN}

Pembelajaran merupakan proses interaksi antara peserta didik dengan pendidik dan sumber belajar pada satu lingkungan belajar. Pembelajaran yang dilakukan pada suatu instansi tidak lepas dari adanya kurikulum. Pembelajaran dan kurikulum memiliki hubungan yang sangat erat. Pembelajaran merupakan bentuk realisasi dari kurikulum. Kurikulum berkaitan dengan pengetahuan atau materi apa yang akan diajarkan, sedangkan pembelajaran berkaitan dengan kegiatan penyajian bahan materi kepada peserta didik.

Berkaitan dengan kurikulum Departemen Pendidikan Teknik Mesin (JPTM) dalam membekali kompetensi para mahasiswa yang diajar, kurikulum tersusun atas beberapa kelompok mata kuliah. Satu diantara kelompok mata kuliah yang ada adalah Mata Kuliah Keahliaan Bidang Studi (MKKBS). MKKBS merupakan materi dasar kejuruan yang membekali para mahasiswa pada saat pelaksanaan Program Latihan Profesi (PLP) di Sekolah Menengah Kejuruan (SMK). Materi yang ada pada MKKBS hendaknya memiliki keterkaitan dan kesesuaian dengan materi Mata Pelajaran Produktif (MPP) di SMK. Satu diantaranya adalah materi mata kuliah teknik refrigerasi yang merupakan mata kuliah dasar kejuruan yang

\footnotetext{
${ }^{1}$ Mahasiswa Departemen Pendidikan Teknik Mesin FPTK UPI

${ }^{2}$ Dosen Departemen Pendidikan Teknik Mesin FPTK UPI

${ }^{3}$ Dosen Departemen Pendidikan Teknik Mesin FPTK UPI
} 
harus dimiliki oleh setiap mahasiswa pada bidang keahliaan teknik Refrigerasi dan Tata Udara (RTU).

Fakta yang ada selama ini berkaitan dengan pelaksanaan PLP kependidikan dapat dideskripsikan bahwa mahasiswa sebagai pendidik di SMK, sebagian masih mengalami kesulitan dalam menguasai materi yang harus disampaikan kepada para peserta didik. Permasalahan ini tentu menjadi hambatan tersendiri, penyesuaian harus dilakukan sebelum langsung berhadapan dengan peserta didik di kelas. Materi yang harus disampaikan kepada peserta didik di SMK terkadang tidak pernah diperoleh peserta PLP sebelumnya pada saat mengikuti pembelajaran yang ada di perguruan tinggi. Fakta menunjukan bahwa materi yang diajarkan di perguruan tinggi, khususnya materi kejuruan yang ada di JPTM belum pernah ditinjau kesesuainnya dengan materi yang dibutuhkan di SMK.

Permasalahan yang ada khususnya berhubungan dengan komponen isi kurikulum kaitannya dengan prinsip relevansi pada materi teknik refrigerasi belum pernah dilakukan. Bertolak belakang dengan prinsip kurikulum bahwa secara internal kurikulum harus memiliki relevansi di antara komponen-komponen kurikulum (tujuan, bahan, strategi, organisasi dan evaluasi) yang menunjukan suatu keterpaduan kurikulum. Berkaitan dengan prinsip relevansi kurikulum maka penelitian ini bermaksud untuk menghasilkan deskripsi relevansi materi pembelajaran teknik refrigerasi di perguruan tinggi dan di SMK dengan materi standar uji kompetensi yang diujikan (Arifin, 2011).

Pengertian kurikulum sangat fundamental dan menggambarkan posisi sesungguhnya kurikulum dalam suatu proses pendidikan karena senantiasa terkait dengan kegiatan pendidikan itu sendiri. Sistem pendidikan nasional dalam undang-undang nomor 20 tahun 2003 mengartikan kurikulum sebagai seperangkat rencana dan pengaturan mengenai tujuan, isi dan bahan pelajaran serta cara yang digunakan sebagai pedoman penyelenggaraan kegiatan pembelajaran untuk mencapai tujuan pendidikan nasional dan khususnya pendidikan kejuruan (Nasution, 1995).

Perguruan tinggi atau pendidikan tinggi terdiri dari pendidikan akademik dan pendidikan vokasi. Universitas merupakan perguruan tinggi yang menyelenggarakan pendidikan akademik dan dapat menyelenggarakan pendidikan vokasi dalam berbagai rumpun ilmu pengetahuan dan teknologi dan jika memenuhi syarat dapat menyelenggarakan pendidikan profesi. Universitas Pendidikan Indonesia (UPI) sebagai perguruan tinggi yang menghasilkan tenaga pendidik memiliki kurikulum yang dikembangkan dengan menerapkan berbagai pendekatan. Re-desain pendidikan profesional guru menunjukan bahwa 
pengembangan kurikulum UPI adalah kurikulum berbasis sekolah-universitas (school university based-curriculum).

Program pendidikan sarjana (S1) adalah jenjang pendidikan dengan masa studi empat sampai tujuh tahun sesuai dengan rambu-rambu pengembangan kurikulum UPI tahun 2013. Lulusan S1 dikategorikan atas beberapa rumpun ilmu diharapkan memiliki kemampuan memahami karakteristik dan potensi peserta didik serta mampu memfasilitasi perkembangan potensi yang bervariasi secara berkesinambungan. beberapa rumpun ilmu. Rumpun ilmu pendidikan kejuruan menitik beratkan para lulusan untuk memiliki kompetensi dibidang keahliaan yang digelutinya seperti pada program studi pendidikan teknik mesin. Tujuan program studi pendidikan teknik mesin adalah menyelenggarakan pendidikan dalam ruang lingkup pendidikan teknik mesin untuk menyiapkan tenaga pendidik profesional yang berdaya saing global. Melakukan kerjasama dengan lembaga pendidikan seperti dengan SMK, maupun lembaga non pendidikan seperti dengan dunia industri untuk mendukung kompetensi dalam ruang lingkup pendidikan teknik mesin. Program studi S1 JPTM pada dasarnya harus menempuh beban studi 144 hingga 155 Satuan Kredit Semester (SKS) yang terdiri atas beberapa kelompok mata kuliah. Kelompok mata kuliah pada konsentrasi teknik refrigerasi dan tata udara mencakup mata kuliah umum, mata kuliah profesi, mata kuliah keahliaan, dan mata kuliah pilihan.

SMK merupakan satu diantara bentuk satuan pendidikan formal yang menyelenggarakan pendidikan kejuruan pada jenjang pendidikan menengah dan mengutamakan pengembangan kemampuan peserta didik untuk melaksanakan jenis pekerjaan tertentu. SMK memiliki banyak program keahliaan yang menyesuaikan dengan kebutuhan masyarakat sebagaimana ditegaskan dalam penjelasan pasal 15 Undang-undang Sistem Pendidikan Nasional (UUSPN) nomor 20 tahun 2003. SMK secara umum terbagi atas beberap rumpun ilmu. Satu diantara rumpun ilmu pada SMK adalah SMK Teknologi dan Rekayasa yang mencakup pada bidang keahliaan teknik pendingin dan tata udara. Tujuan program keahlian teknik pendingin dan tata udara di SMK adalah untuk memiliki keahlian dan keterampilan dalam kompetensi kejuruan yang sesuai dengan Standar Kompetensi dan Kompetensi Dasar Kejuruan (BSNP, 2014). Sehingga peserta didik mampu memilih karir, berkompetisi dan mengembangkan sikap profesional dalam kompetensi keahlian teknik pendingin dan tata udara. Program pendidikan SMK harus menempuh beberapa kelompok mata pelajaran yakni kelompok mata pelajaran wajib, mata pelajaran pilihan dan mata pelajaran vokasional. 
Berkaitan dengan kurikulum SMK 2013, materi pembelajaran merupakan komponen yang sangat penting dan harus dipersiapkan agar pelaksanaan pembelajaran dapat mencapai sasaran. Sasaran harus sesuai denga kompetensi yang akan dicapai oleh peserta didik. Materi pembelajaran dipilih seoptimal mungkin dengan memperhatikan beberapa aspek yang berkaitan dengan hakikat, fungsi, prinsip maupun prosedur pengembangan materi serta mengukur efektivitas persiapan materi pembelajaran. Materi pembelajaran pada dasarnya harus memperhatikan ranah aspek kognitif, ranah aspek afektif maupun ranah aspek psikomotor. Aspek kognitif dikaitkan dengan intelektual, seperti pengetahuan, pengertian, dan ketrampilan berpikir. Jenis materi yang sesuai untuk ranah kognitif adalah fakta dan konsep. Materi pembelajaran untuk ranah afektif ditentukan berdasarkan perilaku yang menekankan aspek perasaan dan emosi. Jenis materi yang sesuai untuk ranah afektif meliputi rasa dan penghayatan seperti respon, penerimaan, internalisasi, dan penilaian. Aspek psikomotor berkaitan dengan perilaku yang menekankan aspek keterampilan motorik (Sanjaya, 2010).

Materi pembelajaran yang digunakan pada penelitian ini adalah materi teknik refrigerasi bidang keahliaan teknik refrigerasi dan tata udara. Materi teknik refrigerasi dibahas pada mata kuliah teknik refrigerasi di JPTM, sedangkan di SMK dibahas pada mata pelajaran sistem dan instalasi refrigerasi. Materi evaluasi (Arikunto, 2008) yang digunakan adalah materi yang mendukung pada saat pelaksanaa uji kompetensi di SMK pada bidang keahliaan teknik refrigerasi dan tata udara untuk kompetensi perakitan lemari es yang dikeluarkan oleh Badan Standar Nasional Pendidikan (BSNP). Pemilihan ketiga materi karena saling memiliki keterkaitan yang akan dibahas relevansi materinya.

\section{METODE PENELITIAN}

Metode yang digunakan pada penelitian ini adalah menggunakan metode deskriptif analisis dengan pendekatan kuantitatif, yaitu hasil penelitian yang diperoleh kemudian diolah dan dianalisis untuk diambil kesimpulannya. Penggunaan metode ini berdasarkan pada tujuan penelitian, yakni untuk memperoleh angka-angka secara numerikal berupa persentase relevansi antara materi pembelajaran produktif pada kurikulum JPTM dan SMK dengan standar uji kompetensi bidang keahliaan teknik refrigerasi dan tata udara. Metode penelitian deskriptif bertujuan untuk mendapatkan gambaran yang ada. Penelitian dengan pendekatan kuantitatif dilakukan sebagai cara untuk meneliti berbagai aspek dari pendidikan. Penelitian dengan menggunakan pendekatan kuantitatif berlandaskan sampel pada filsafat positivisme, digunakan untuk meneliti pada populasi atau sampel tertentu, pengumpulan data menggunkan 
instrumen penelitian yang meliputi dokumentasi, angket maupun wawancara dengan analisis data yang bersifat kuantitatif, dengan tujuan untuk menguji hipotesis yang telah ditetapkan.

Menetapkan metode penelitian yang akan digunakan dalam proses pengambilan data, membahas masalah melalui data yang akan diteliti, dan data informasi yang diperoleh dari responden diolah untuk dianalisis. Melaporkan hasil penelitian dan proses penelitian yang dilakukan baik secara verbal ataupun menggunakan tabel. Menyimpulkan penelitian untuk memperoleh jawaban melalui langkah penyelesaian permasalahan dalam penelitian.

\section{HASIL PENELITIAN}

Data yang digunakan adalah materi MKKBS teknik refrigerasi yang ada pada kurikulum 2013 JPTM dengan materi sebanyak tujuh pokok bahasan. Materi perkuliahan teknik refrigerasi direlevansikan terhadap materi MPP sistem dan instalasi refrigerasi yang memiliki tujuh pokok bahasan. Kesesuaian materi divisualisasikan melalui diagram $\mathrm{x}-\mathrm{y}$ (Gambar 1). Sumbu-x yang berisi materi pelajaran sistem dan instalasi refrigerasi, sedangkan sumbu-y berisi materi perkuliahan teknik refrigerasi. Relevansi antara kedua subjek materi ditandai dengan bulatan di dalam kotak.

\section{MATERI TEKNIK REFRIGERASI}

(1) Sejarah dan Aplikasi Refrigerasi

(2) Dasar Refrigerasi

(3) Komponen Utama Refrigerasi

(4) Peralatan Kerja Refrigerasi

(5) Refrigeran dan oli refrigeran

(6) Sistem Kompresi Uap

(7) Estimasi Beba Refrigerasi

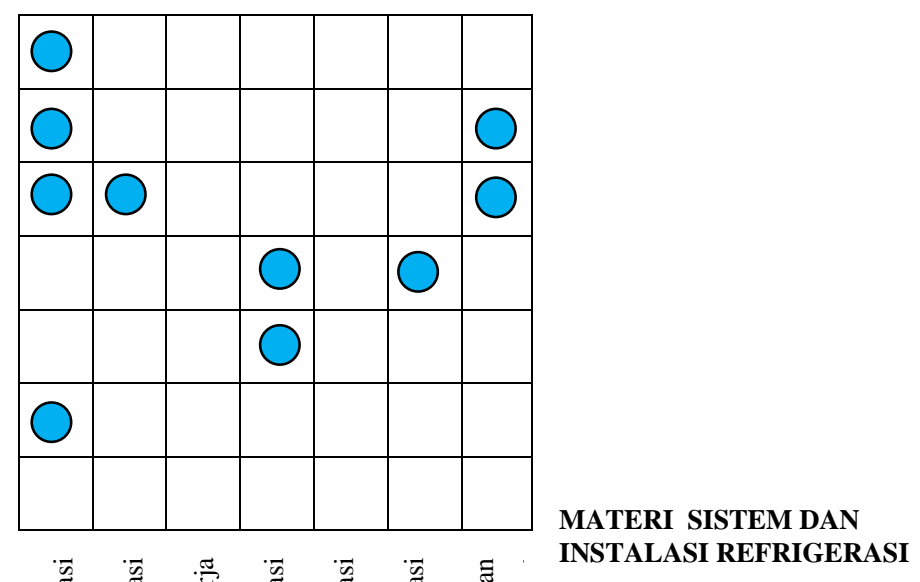

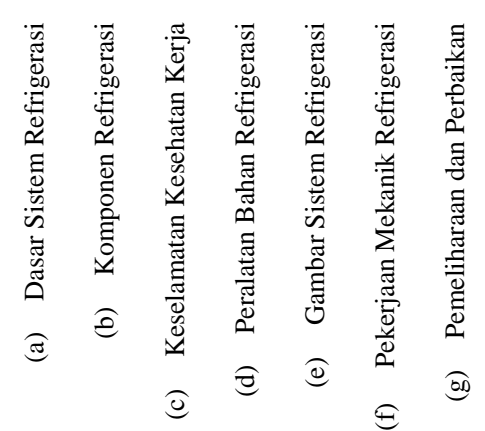

INSTALASI REFRIGERAS

Gambar 1. Diagram Relevansi Materi Mata Kuliah Teknik Refrigerasi dengan Materi Pelajaran Sistem dan Instalasi Refrigerasi 
Data relevansi antara materi mata kuliah teknik refrigerasi dengan materi pelajaran sistem dan instalasi refrigerasi secara umum memiliki tingkat kesesuaian yang relevan yakni 71,43\%. Persentase ini diperoleh dengan cara membandingkan jumlah materi yang relevan terhadap jumlah keseluruhan materi, yakni lima materi yang relevan dari tujuh materi pelajaran sistem dan instalasi refrigerasi. Materi yang relevan diantaranya meliputi: (a) Dasar sistem refrigerasi; (b) Komponen refrigerasi; (d) Peralatan bahan refrigerasi; (f) Pekerjaan mekanik refrigerasi; dan (g) Pemeliharaan dan perbaikan refrigerasi. Dua materi lainnya yakni (c) Materi keselamatan dan kesehatan kerja dan (e) Materi gambar sistem refrigerasi tidak memiliki relevansi dengan materi teknik refrigerasi yang ada di JPTM. Tidak sesuainya materi atau tidak adanya materi teknik refrigerasi yang mendukung materi gambar sistem refrigerasi karena materi terpisah dari materi perkuliahan teknik refrigerasi yakni terdapat pada mata kuliah AutoCAD dan gambar refrigerasi yang merupakan materi perkuliahan perluasan. Materi keselamatan dan kesehatan kerja baru ditambahkan terpisah dengan mata kuliah teknik refrigerasi untuk kurikulum 2013.

Kesesuaian materi teknik refrigerasi yang ada di JPTM terhadap kebutuhan materi yang digunakan untuk mengevaluasi kompetensi para peserta didik yakni pada pelaksanaan standar uji kompetensi kejuruan perlu dilakukan. Tujuannya untuk mengetahui sejauh mana materi teknik refrigerasi dengan materi yang diujikan di SMK. Materi yang diujikan sudah seharusnya sesuai dengan materi yang dibekali kepada para mahasiswa yang akan mengajar para peserta didik di SMK. Materi yang tidak sesuai akan menjadi hambatan tersendiri bagi mahasiswa pada saat mengajar di depan kelas. Hal ini akan mempengaruhi kompetensi yang akan dimiliki peserta didik yang akan diujikan kompetensinya pada pelaksanaan standar uji kompetensi kejuruan.

Data relevansi antara materi mata kuliah teknik refrigerasi dengan materi uji kompetensi secara umum memiliki tingkat kesesuaian yang relevan yakni $75 \%$. Persentase ini diperoleh dengan cara membandingkan jumlah materi yang relevan terhadap jumlah keseluruhan materi, yakni sembilan materi yang relevan dari dua belas materi uji kompetensi. Kesesuaian materi divisualisasikan melalui diagram x-y (Gambar 2). Sumbu-x yamg berisi materi uji kompetensi dan sumbu-y berisi materi mata kuliah teknik refrigerasi. Kotak dengan bulatan menunjukan adanya relevansi antara materi pembelajaran.

Diagram (Gambar 2) menjelaskan bahwa materi teknik refrigerasi sebagian memenuhi kebutuhan materi yang digunakan untuk uji kompetensi. Tiga dari dua belas materi yang ada pada uji kompetensi tidak terpenuhi kesesuaiannya oleh mata kuliah teknik refrigerasi, yakni 
materi (a) atribut keselamatan dan kesehatan kerja, (d) peralatan keamanan kerja, dan (e) gambar kerja. Tidak terpenuhinya materi karena berdasarkan kurikulum 2013, materi tersebut menjadi satu mata kuliah tersendiri sebagai materi MKKBS. Sembilan diantara materi uji kompetensi yang memiliki kesesuaian dengan materi teknik refrigerasi, diantaranya (b) peralatan kerja refrigerasi, (c) bahan kerja refrigerasi, (f) pekerjaan dasar mekanik refrigerasi, (g) pemvakuman unit sistem refrigerasi, (h) pengisian unit sistem refrigerasi, (i) pemeriksaan unit sistem refrigerasi, (j) pemeliharaan dan perbaikan unit sistem refrigerasi, (k) operasi unit sistem refrigerasi, dan (l) pengujian unit sistem refrigerasi.

\section{MATERI TEKNIK REFRIGERASI}

(1) Sejarah dan Aplikasi Refrigerasi

(2) Dasar Refrigerasi

(3) Komponen Utama Refrigerasi

(4) Peralatan Kerja Refrigerasi

(5) Refrigeran dan oli refrigeran

(6) Sistem Kompresi Uap

(7) Estimasi Beba Refrigerasi

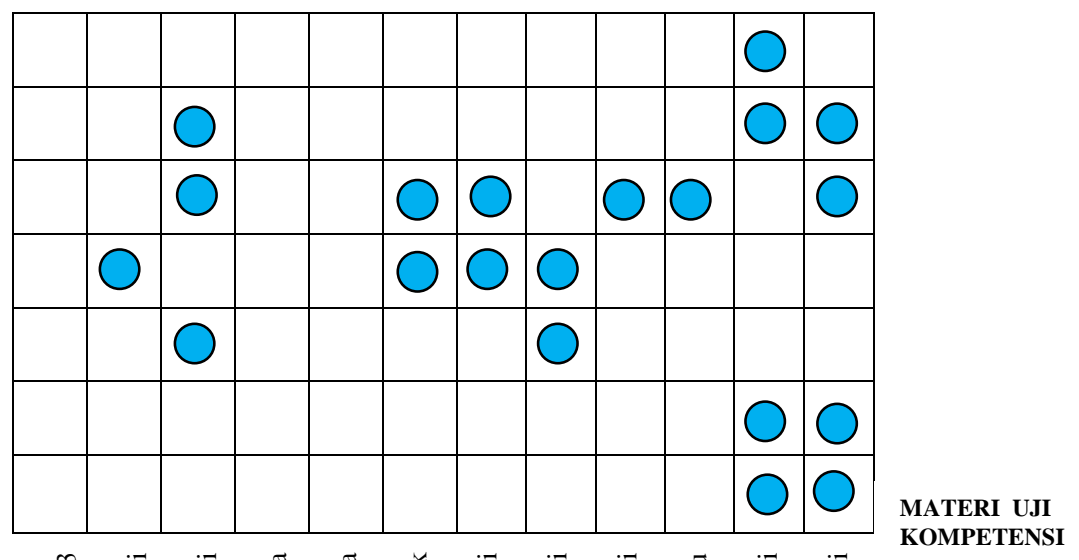

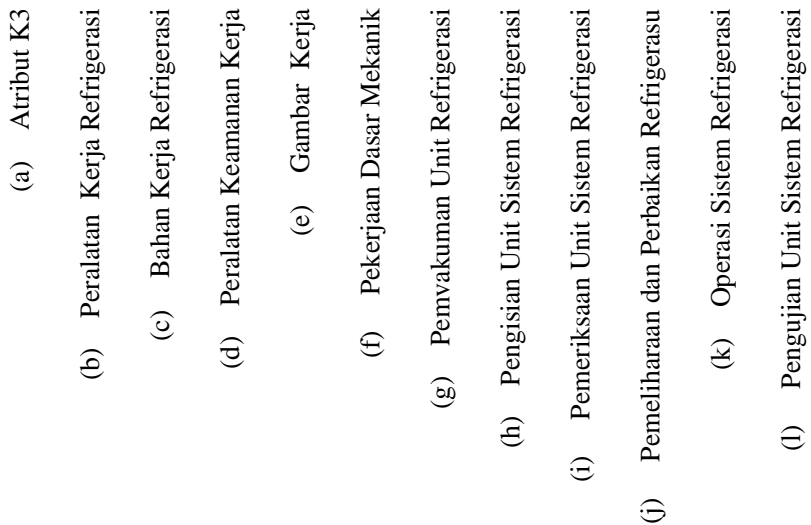

Gambar 2. Diagram Relevansi Materi Mata Kuliah Teknik Refrigerasi dengan Materi Uji Kompetensi

Pendeskripsian relevansi materi pelajaran sistem dan instalasi refrigerasi dengan materi uji kompetensi. Tujuannya adalah untuk mengetahui seberapa besar materi yang ada untuk membekali kompetensi para peserta didiknya. Materi yang digunakan pada saat pembelajaran maupun digunakan untuk evaluasi pembelajaran yang ada di SMK seharusnya memiliki keterkaitan yang tinggi karena pada saat proses pembelajaran, peserta didik dibekali dengan kompetensi yang diujikan. Satu diantaranya adalah materi pembelajaran sistem dan 
instalasi refrigerasi yang mendukung tentang kompetensi para peserta didik pada keahliaan pekerjaan dasar refrigerasi untuk lemari pendingin atau lemari es. Materi pelajaran sistem dan instalasi refrigerasi memiliki tujuh pokok bahasan materi, sedangkan materi standar uji kompetensi memiliki dua belas materi.

Data relevansi antara materi mata pelajaran sistem dan instalasi refrigerasi dengan materi uji kompetensi memiliki tingkat kesesuian yang sangat relevan yakni 91,67\%. Persentase ini diperoleh dengan cara membandingkan jumlah materi yang relevan terhadap jumlah keseluruhan materi yakni sebelas materi yang relevan dari dua belas materi uji kompetensi. Kesesuaian materi divisualisasikan melalui diagram x-y (Gambar 3). Sumbu-x berisi materi mata pelajaran sistem dan instalasi refrigerasi dan sumbu-y berisi materi uji kompetensi. Kotak dengan bulatan menunjukan adanya relevansi antara materi pembelajaran.

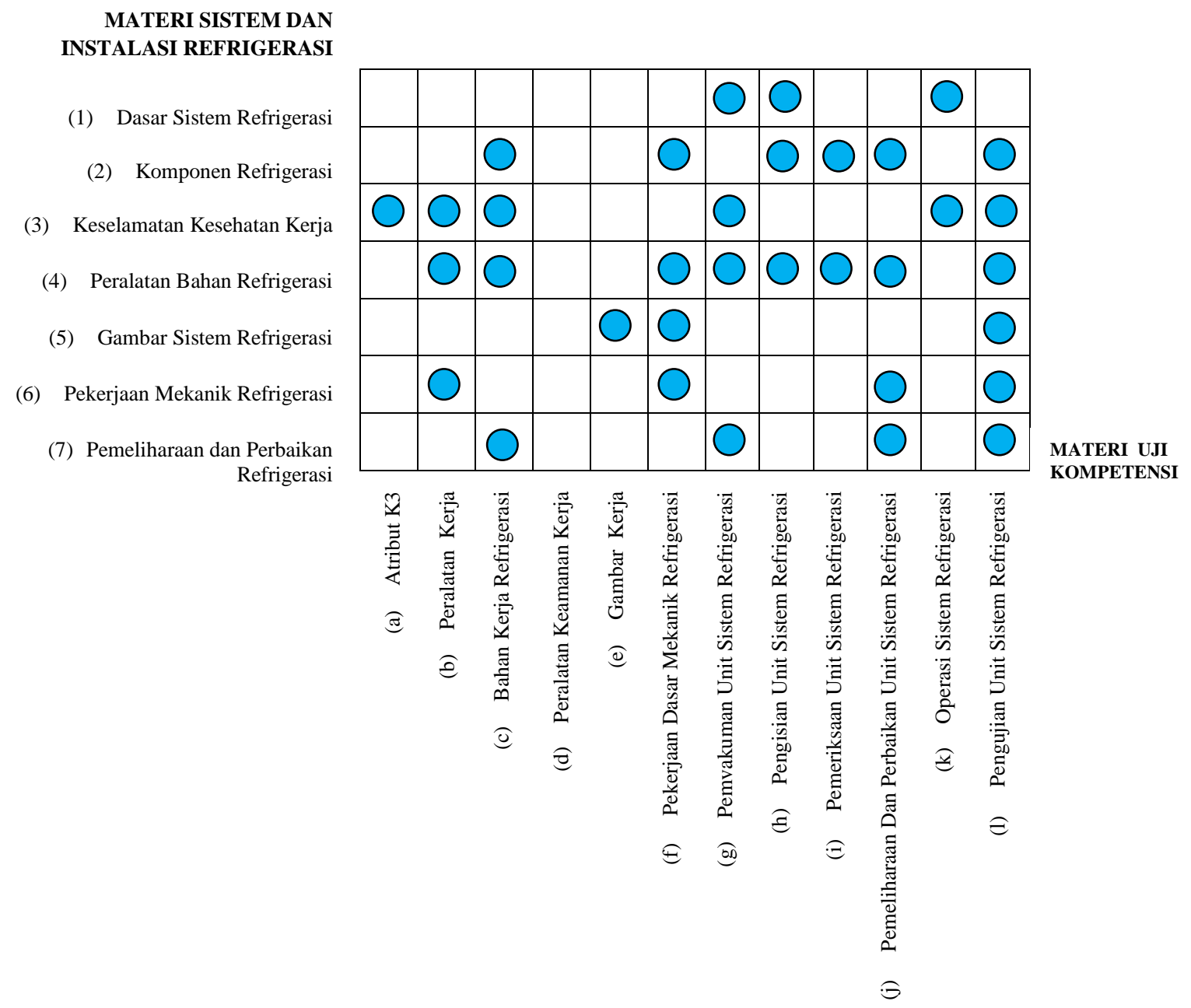

Gambar 3. Diagram Relevansi Materi Sistem dan Instalasi Refrigerasi dengan Materi Pelajaran Uji Kompetensi 
Diagram relevansi menunjukan bahwa materi yang memiliki kesesuaian sebanyak sebelas materi pokok dan yang tidak sesuai ada satu materi pokok. Setiap materi pokok yang sesuai pada dasarnya memiliki keterkaitan baik hanya satu atau lebih dari satu materi mata pelajaran yang mendukung meteri uji kompetensi. Sebelas diantara materi uji kompetensi memiliki kesesuaian dengan materi teknik refrigerasi, diantaranya (a) atribut keselamatan dan kesehatan kerja, (c) bahan kerja refrigerasi, (d) peralatan keamanan kerja, (e) gambar kerja, (f) pekerjaan dasar mekanik refrigerasi, (g) pemvakuman unit sistem refrigerasi, (h) pengisian unit sistem refrigerasi, (i) pemeriksaan unit sistem refrigerasi, (j) pemeliharaan dan perbaikan unit sistem refrigerasi, (k) operasi unit sistem refrigerasi, dan (l) pengujian unit sistem refrigerasi. Materi mata pelajaran yang tidak sesuai atau tidak diperoleh relevansi dukungan untuk materi uji kompetensi adalah materi (d) peralatan keamanan kerja. Materi keselamatan kerja khususnya untuk peralatan keamanan kerja seperi fire safety dan yang lainnya terkadang kurang diperhatikan karena pengawasan terhadap faktor kecelakaan kerja masih dioptimalkan. Pembekalan materi perlu dilakukan untuk kesiapan peserta didik jika terjadi kecelakaan yang tidak diharapkan.

\section{PEMBAHASAN}

Informasi yang diperoleh berdasarkan hasil penelitian mengenai relevansi materi mata kuliah teknik refrigerasi dan materi pelajaran sistem dan instalasi refrigerasi dengan materi yang digunakan untuk uji kompetensi di SMK secara umum memiliki tingkat kesesuaian dalam kategori relevan. Mata kuliah teknik refrigerasi memiliki persentase relevansi materi sebesar $71,43 \%$ dengan materi yang dibutuhkan untuk pembelajaran peserta didik dan $75 \%$ dengan materi yang digunakan untuk uji kompetensi di SMK. Persentase relevansi materi mata pelajaran sistem dan instalasi refrigerasi dengan materi yang digunakan untuk uji kompetensi sendiri sebesar 91,67\%. Kesesuaian materi sebagian sudah mencukupi keluasan dan kedalaman materi yang dibutuhkan dan sebagian belum mencukupi. Materi yang tidak sesuai sebagian merupakan materi yang ada pada mata kuliah yang berbeda atau terpisah pada kurikulum 2013 JPTM. Kesesuaian materi teknik refrigerasi tidak sepenuhnya memenuhi kebutuhan materi pembelajaran sistem instalasi refrigerasi dan materi uji kompetensi yang ada di SMK (Gambar 4). 


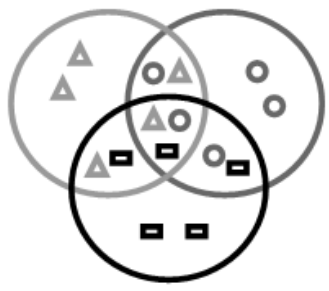

\footnotetext{
Keterangan:

$\mathbf{\Delta}$ = Materi Mata Kuliah Teknik Refrigerasi

$\mathbf{O}$ = Materi Sistem dan Instalasi Refrigerasi

$\boldsymbol{\square}$ = Materi Uji Kompetensi
}

Gambar 4. Diagram Relevansi Materi Teknik Refrigerasi dan Materi Sistem dan Instalasi Refrigerasi dengan Materi Uji Kompetensi

Diagram menjelaskan bahwa materi teknik refrigerasi sebagian memiliki kesesuaian cakupan keluasan dan kedalaman materi baik dengan materi pelajaran sistem dan instalasi refrigerasi maupun dengan materi yang digunakan untuk uji kompetensi. Artinya ketiga subjek materi secara bersama-sama memiliki keterkaitan. Kesesuaian yang lain dapat terjadi yakni kesesuaian yang hanya melibatkan dua subjek materi, baik kesesuaian antara materi teknik refrigerasi dengan materi sistem dan instalasi refrigerasi maupun sebaliknya dengan materi uji kompetensi. Materi yang tidak memiliki kesesuaian bukan berarti tidak dibutuhkan melainkan merupakan materi pendukung untuk materi yang ada khususnya pada mata kuliah teknik refrigerasi.

Materi sistem dan instalasi refrigerasi yang ada di SMK secara umum memiliki persentase kesesuaian terhadap materi uji kompetensi yang lebih besar dibandingkan dengan persentase kesesuaian yang ada pada materi teknik refrigerasi yang diajarkan untuk para mahasiswa di JPTM. Keluasan dan kedalaman cakupan materi yang ada di SMK lebih optimal untuk membekali para peserta didik dalam menghadapi uji kompetensi. Kondisi ini sangat memungkinkan karena materi sistem dan instalasi refrigerasi secara formal akan diujikan pada saat pelaksanaan uji kompetensi (Purwanto, 2010). Cakupan keluasan dan kedalaman materi teknik refrigerasi kurang memenuhi kebutuhan baik untuk pembelajaran maupun pelaksanaan uji kompetensi di SMK. Permasalahan ini terjadi karena standar tentang acuan materi yang diajarkan di setiap jenjang pendidikan sampai saat ini belum ada kejelasan. Idealnya materi yang ada di perguruan tinggi lebih kompleks dengan materi yang ada di SMK, baik materi untuk proses pembelajaran maupun materi untuk mendukung uji kompetensi (Gambar 5). 


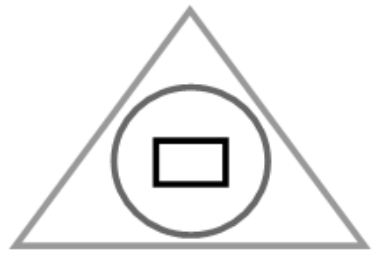

$\begin{aligned} & \text { Keterangan: } \\ \mathbf{A} & =\text { Materi Mata Kuliah Teknik Refrigerasi } \\ \mathbf{0} & =\text { Materi Sistem dan Instalasi Refrigerasi } \\ \mathbf{\square} & =\text { Materi Uji Kompetensi }\end{aligned}$

Gambar 5. Diagram Relevansi Ideal Materi Teknik Refrigerasi dan Materi Sistem dan Instalasi Refrigerasi dengan Materi Uji Kompetensi

Diagram menjelaskan bahwa materi teknik refrigerasi memiliki kesesuaian cakupan keluasan dan kedalaman yang sangat kompleks dengan materi sistem dan instalasi refrigerasi serta materi yang digunakan untuk mendukukng uji kompetensi di SMK. Kondisi ini berlaku untuk semua materi mata kuliah yang ada di perguruan tinggi, khususnya yang berhubungan dengan kompetensi yang akan dimiliki mahasiswa untuk dapat diajarkan kepada peserta didik ketika mengajar di SMK.

Berdasarkan tinjauan yang telah dilakukan penulis pada penelitian ini, khususnya untuk guru materi pelajaran dan dosen mata kuliah diharapkan dapat menyesuaikan dan mempertimbangkan tambahan materi yang mungkin perlu disampaikan untuk membekali para peserta didik yang diajar. Penyesuaian materi sangat mungkin terjadi, karena seiring berjalannya waktu kurikulum senantiasa mengalami perkembangan, sehingga setiap materi yang disusun harus sesuai dengan kurikulum yang berlaku.

\section{KESIMPULAN}

Materi pembelajaran pada mata kuliah teknik refrigerasi secara umum termasuk kategori relevan dengan kebutuhan materi yang digunakan untuk proses pembelajaran maupun materi yang digunakan untuk uji kompetensi di SMK. Materi yang digunakan untuk proses pembelajaran di SMK sendiri memiliki relevansi yang lebih tinggi untuk mendukung kebutuhan materi uji kompetensi. Relevansi materi dapat dilihat dari setiap materi pokok bahasan dalam mendukung materi yang dibutuhkan, meskipun ada beberapa materi yang belum terpenuhi. Materi yang belum terpenuhi sebagian merupakan materi yang ada pada pembelajaran di luar subjek penelitian. Materi yang dimaksud adalah materi keselamatan kesehatan kerja dan gambar kerja. Kedua materi tidak menutup kemungkinan untuk dibahas pada materi pembelajaran teknik refrigerasi. Materi teknik refrigerasi yang belum terlihat relevansinya bukan berarti materi tersebut harus dihapus, tetapi bisa dijadikan wawasan tambahan untuk bekal mengajar para peserta didik. 


\section{DAFTAR PUSTAKA}

Arifin, Z. (2011). Konsep dan Model Pengembangan Kurikulum. Bandung: PT. Remaja Rosdakarya Offset.

Arikunto, S. (2008). Dasar-Dasar Evaluasi Pendidikan. Jakarta: Bumi Aksara

BSNP. (2014). Materi Uji Kompetensi SMK Teknik Pendingin dan Tata Udara. [Online]. http://www.slideshare.net/wincibal/1218-p2spkteknik-pendingin-dan-tata-udara. [09 April 2014].

Nasution, S. (1995). Asas-asas Kurikulum. Jakarta: Bumi Aksara

Sanjaya. W. (2010). Strategi Pembelajaran Berorientasi Standar Proses Pendidikan. Jakarta: Kencana.

Purwanto, N. (2010). Prinsip-prinsip dan Teknik Evaluasi Pengajaran. Bandung: PT Remaja Rosdakarya. 